\title{
Grain Yield Enhancement through Fungicide Application on Maize Hybrids with Different Susceptibility to Northern Corn Leaf Blight
}

\author{
G. TESTA, A. REYNERI, F. CARDinale and M. BLANDinO* \\ Università di Torino, Dipartimento di Scienze Agrarie, Forestali e Alimentari, \\ Largo Paolo Braccini, 2, 10095 Grugliasco (TO), Italy \\ (Received 29 May 2014; Accepted 4 September 2014; \\ Communicated by J. Kolmer)
}

\begin{abstract}
Foliar fungicides are widely used to control pests on several crops and, from mid-2000s, have become more common on maize. The yield advantages derived from foliar fungicides on maize, as for other crops, could be related not only to the direct control of the disease, but also to physiological effects on the plant. The aim of the research was to evaluate the response of maize to the application of an azoxystrobin and propiconazole mixture. The fungicide was applied to hybrids with different susceptibility to northern corn leaf blight (NCLB) foliar disease at the beginning of stem elongation or at the tassel emergence stage. The best application timing resulted to be at the tassel emergence stage for both pathogen control and grain yield. The treatment effectively controlled disease development on the two hybrids susceptible to NCLB. However, the yield of the moderately-resistant hybrid increased unexpectedly to a comparable extent, even though no significant fungal containment was detected from a visual inspection. The peroxidase and superoxide dismutase activity, the protein leaf content and the translocation efficiency of carbohydrates from the leaf to the ear were not influenced by the fungicide treatments, differently from what had been previously shown on wheat. The authors suggest that rather than the improved metabolism of the reactive oxygen species, the positive effect of the fungicide on the moderately-resistant hybrid is due to other physiological mechanisms. It is hypothesized that the fungicide leads to better yields as it prevents the allocation of metabolic resources to actively defend against the pathogen.
\end{abstract}

Keywords: maize, azoxystrobin, propiconazole, northern corn leaf blight, plant physiology

\section{Introduction}

Crop protection products are utilized in modern maize production, to preserve yield potential and grain quality requirements (Diedhiou et al. 2004). Among these pesticides, the use of foliar fungicides has increased greatly from mid-2000s in the United States (Wise and

* Corresponding author; E-mail: massimo.blandino@unito.it; Phone: +39-011-6708895;

Fax +39-011-6708798. 
Mueller 2011) and in other countries such as Brazil (Cunha et al. 2010) and Canada (Hooker et al. 2009), while their introduction into European Union countries has been more recent. Foliar fungicides are usually applied to control several leaf diseases. In temperate areas, northern corn leaf blight (NCLB) is the most common foliar disease for maize, and it is caused by Exserohilum turcicum (White 1999).

Demethylation inhibitor (DMI) fungicides, especially those belonging to the azole family, are the most efficient in controlling E. turcicum development both in vitro and in field conditions (Bowen and Pedersen 1988; Kumar et al. 2009). Quinone outside inhibitor (QoI) foliar fungicides are systemic fungicides that mostly belong to the strobilurines family and target the mitochondrial respiration of fungi. They can also prevent foliar diseases on maize (Bradley and Ames 2010), moreover this group of fungicides has been shown to provide some physiological benefits when applied to other crops. Their application to wheat at heading has been shown to increase the activity of antioxidant enzymes, such as peroxidase (POD) and superoxide dismutase (SOD), and the leaf protein content (LPC) on flag leaves at the onset of senescence (Wu and von Tiedemann 2001; Zhang et al. 2010; Wang et al. 2011). This effect leads to delayed senescence and longer stay-green during ripening stages, and could be responsible for the higher yields observed, compared to the untreated controls. Senescence is in fact a consequence, among other factors, of reactive oxygen species (ROS) accumulation (Thompson et al. 1987; Alscher et al. 1997; Prochazkova et al. 2001), which can be hastened by abiotic and biotic stresses such as high light and ozone concentration, drought and pathogen attack. Senescence is first characterized by a reduction, and then by a cessation of photosynthetic activity, due to a massive loss of organelle integrity and chlorophyll (del Rio et al. 1998).

The control of foliar diseases and the yield benefit obtained by spraying a mixture of DMI and QoI fungicides on maize have already been described (Da Costa and Boller 2008; Blandino et al. 2012). The aim of this research was to evaluate the efficacy of a foliar fungicide mixture, containing molecules of the strobilurins and azoles families, on hybrids with different genetic susceptibility to NCLB, in order to access potential yield enhancement in temperate areas where usually the foliar disease pressure is low. Furthermore, the hypothesis was made that a modulation of the ROS metabolism and of foliar senescence could be responsible for a share of the yield increase, independently of disease control, as previously reported for wheat (Zhang et al. 2010).

\section{Materials and Methods}

\section{Experimental site and treatments}

The experiment was carried out in the 2011 and 2012 growing seasons, at two sites with different pedoclimatic conditions in NW Italy: site A (Saluggia, $45^{\circ} 14^{\prime} \mathrm{N}, 8^{\circ} 00^{\prime} \mathrm{E}$; altitude $194 \mathrm{~m}$, shallow sandy soil, Typic Hapludalfs, according to the USDA classification) and site B (Villafranca, $44^{\circ} 47^{\prime} \mathrm{N}, 7^{\circ} 33^{\prime}$ E, altitude $253 \mathrm{~m}$, deep and fertile sandy soil, Typic Eutrochrepts, according to the USDA classification). 
The compared treatments were factorial combinations, in natural conditions, of:

- 3 different maize hybrids with different NCLB susceptibility:

- Pioneer 3235, FAO maturity 600, 130 days relative to maturity, fully susceptible.

- Syngenta NX7034, FAO maturity 600; 128 days relative to maturity, fairly susceptible.

- Syngenta NX7234, FAO maturity 500; 127 days relative to maturity, moderately-resistant.

- 3 fungicide application timings:

- T0, untreated control.

- T1, beginning of stem elongation, Growth Stage (GS) 30 (Lancashire et al. 1991) at the feasible height limit to allow entrance to a common farm ground sprayer.

- T2, tassel emergence (GS 51).

The previous crop was maize in both 2011 and 2012. The following agronomic practices refer to the ordinary crop management of maize in North Italy. Planting was carried out after an autumn ploughing to a $30 \mathrm{~cm}$ depth, thus incorporating the debris in the soil, followed by disk harrowing to prepare a proper seedbed. The experimental fields received 250,100 and $100 \mathrm{~kg} \mathrm{ha}^{-1}$ of $\mathrm{N}, \mathrm{P}_{2} \mathrm{O}_{5}$ and $\mathrm{K}_{2} \mathrm{O}$, respectively, each year. Both sites were irrigated using the furrow surface method to maintain the water-holding capacity between 33 and $200 \mathrm{kPa}$. Weed control was conducted at pre-emergence with mesotrione $(0.15 \mathrm{~kg} \mathrm{AI}$ $\mathrm{ha}^{-1}$ ) S-metolachlor (1.25 kg AI ha $\left.{ }^{-1}\right)$ and terbuthylazine $\left(0.75 \mathrm{~kg} \mathrm{AI} \mathrm{ha}^{-1}\right)$ (Lumax ${ }^{\circledR}$, Syngenta Crop Protection S.p.A., Milan, Italy). All the trials were sprayed at GS 75 with pyrethroid lambda-cyhalothrin insecticide (Karate ${ }^{\circledR}$ Zeon, Syngenta Crop Protection S.p.A., Milan, Italy) at $0.019 \mathrm{~kg} \mathrm{AI} \mathrm{ha}^{-1}$.

A mixture of QoI and DMI fungicides was applied: azoxystrobin and propiconazole $\left(\right.$ Quilt Xcel ${ }^{\circledR}$ ). The formulation was as follows: emulsifiable concentrate (EC), Syngenta Crop Protection AG, Basel, Switzerland) applied at 0.141 and $0.122 \mathrm{~kg} \mathrm{AI} \mathrm{ha}^{-1}$ for azoxystrobin and propiconazole, respectively ( $1 \mathrm{~L}$ of commercial product ha $\left.{ }^{-1}\right)$. The treatments were carried out using a self-propelled ground sprayer (Eurofalcon E140 ${ }^{\circledR}$, Finotto) with a hydraulically adjustable working height of 0.40 to $4.30 \mathrm{~m}$. Flat-fan nozzles were used to spray a volume of $400 \mathrm{~L} \mathrm{ha}^{-1}$, at a pressure of $200 \mathrm{kPa}$, with a median droplet-size range of 145-225 $\mu \mathrm{m}$. A fan was used to blow low-pressure air towards the crop, while the nozzles were spraying, in order to increase the penetration of the treatment into the canopy. The operation speed was $10 \mathrm{~km} \mathrm{~h}^{-1}$. The planting and harvest dates as well as the fungicide treatments and leaf sample collection, are reported in Table 1 for each year and site.

The experiment was carried out at each location, with a split-plot design: the hybrid was considered as the main factor and the fungicide treatment as a sub-plot factor with 6 replicates. Each plot consisted of 12 rows $0.75 \mathrm{~cm}$ apart and $15 \mathrm{~m}$ long. The plot alleys, orthogonal to the maize rows, were one meter wide. 
Table 1. Main trial information and fungicide applications

\begin{tabular}{|c|c|c|c|c|}
\hline \multirow{2}{*}{$\begin{array}{l}\text { Year } \\
\text { Site }\end{array}$} & \multicolumn{2}{|c|}{2011} & \multicolumn{2}{|c|}{2012} \\
\hline & Saluggia & Villafranca & Saluggia & Villafranca \\
\hline Treatment" & \multicolumn{4}{|c|}{ Date of fungicide application } \\
\hline $\mathrm{T} 1$ & May $30^{\text {th }}$ & May $30^{\text {th }}$ & Jun $5^{\text {th }}$ & Jun $4^{\text {th }}$ \\
\hline $\mathrm{T} 2$ & Jun $20^{\text {th }}$ & Jun $20^{\text {th }}$ & $\mathrm{Jul} 7^{\text {th }}$ & Jun $27^{\text {th }}$ \\
\hline Planting date & Apr $1^{\text {st }}$ & Apr $9^{\text {th }}$ & $\operatorname{Mar} 28^{\text {th }}$ & $\operatorname{Mar} 24^{\text {th }}$ \\
\hline Harvest date & Sep $12^{\text {th }}$ & Sep $22^{\text {nd }}$ & Sep $17^{\text {th }}$ & Sep $17^{\text {th }}$ \\
\hline GS 81 leaf sampling & Jul $21^{\text {st }}$ & Jul $28^{\text {th }}$ & Jul $25^{\text {th }}$ & Jul $26^{\text {th }}$ \\
\hline GS 85 leaf sampling & Aug $3^{\text {rd }}$ & Aug $24^{\text {th }}$ & Aug $22^{\text {nd }}$ & Aug $23^{\text {rd }}$ \\
\hline
\end{tabular}

${ }^{\wedge} \mathrm{T} 1$, application at the beginning of stem elongation (GS 30); T2, application at tassel emergence (GS 51).

\section{NCLB assessment}

Fifteen plants per plot were visually evaluated at flowering (GS 63), during the milk stage (GS 75) and dough stage (GS 85) in order to establish the incidence and severity of the NCLB symptoms. Five leaves were considered for each plant: the ear leaf and the 2 leaves above and below the ear. Disease incidence was calculated as the percentage of leaves with symptoms (considering 75 leaves per plot), while severity was calculated as the average percentage of leaf surface with symptoms. An index of 1 to 7 was used, in which each numerical value corresponds to a percentage interval of foliar surfaces exhibiting visible symptoms according to the following scale: $1=$ no symptoms, $2=1-2 \%, 3=3-5 \%$; $4=6-10 \%, 5=10-25 \%, 6=26-50 \%, 7>50 \%$. The NCLB severity scores were converted into percentages of leaf surface showing symptoms and each score was replaced with the mid-point of the interval.

\section{Enzymatic activities}

The enzymatic activity assays were performed on the NX7234 hybrid, which is moderately resistant to NCLB. The ear leaves were sampled on each plot at the beginning of the dough stage (GS 81) and at the full dough stage (GS 85) for the total protein extracts. The middle part of six ear leaves, free of visible fungal lesions, were pooled into one sample, immediately frozen in liquid nitrogen and then stored at $-25^{\circ} \mathrm{C}$. The collected tissues were rinsed with distilled water and then ground in liquid nitrogen for the extraction. Five $\mathrm{ml}$ of pre-cooled Na-phosphate buffer $(50 \mathrm{mM}, \mathrm{pH} 7.8)$ containing EDTA-Na $\mathrm{N}_{2}(0.1 \mathrm{mM})$ and polyvinylpyrrolidon $(1 \% \mathrm{w} / \mathrm{w})$ was added to $1 \mathrm{~g}$ of leaf tissue powder and vortexed briefly. The homogenates were centrifuged at $3700 \mathrm{~g}$ for $30 \mathrm{~min}$ at $4^{\circ} \mathrm{C}$. The supernatants were collected and stored at $-25^{\circ} \mathrm{C}$ for further use as tissue extracts.

The total soluble leaf protein content (LPC) of the crude extract was assayed by means of the Bradford absorbance method (Bradford 1976). Ten $\mu 1$ of crude extract was pipetted in a test tube containing $90 \mu \mathrm{l}$ of distilled water, and $1 \mathrm{ml}$ of the Bradford solution (AppliChem, Darmstadt, Germany) was added for protein quantification in order to start the reaction. Absorbance was read after 10 minutes at $595 \mathrm{~nm}$. The calibration curve was generated from five calibration points with Bovine Serum Albumin (BSA) at growing 
concentrations of $2 \mathrm{mg} \mathrm{ml}^{-1}$ to $10 \mathrm{mg} \mathrm{ml}^{-1}$. The blank was assayed by reading the absorbance of a tube containing no BSA.

The peroxidase (POD) activity assay was based on the determination of the initial rate of guaiacol oxidation by $\mathrm{H}_{2} \mathrm{O}_{2}$ (Ekmekci and Terzioglu 2005). The reaction mixture contained $0.75 \mathrm{ml}$ of Na-phosphate buffer (pH 5.5) (50 mM), $0.5 \mathrm{ml}$ of guaiacol (50 mM), 0.5 $\mathrm{ml}$ of $\mathrm{H}_{2} \mathrm{O}_{2}(2 \%)$ and $1230 \mu \mathrm{l}$ of distilled water ( $\mathrm{Zhang}$ et al. 2010). Two readings were performed at $470 \mathrm{~nm}$ : 20 seconds and 60 seconds after adding $20 \mu 1$ of crude extract. The difference between these two values was taken as the guaiacol oxidation rate. A calibration curve was generated by adding $20 \mu \mathrm{l}$ of a growing concentration, starting from 5 to 16 $\mathrm{u} \mathrm{ml}^{-1}$, of a commercial POD extracted from horseradish (Sigma Aldrich, product number P8375-1KU) to the reaction mixture instead of the crude extract. Distilled water was used as a blank sample. One POD enzymatic unit (e.u.) is defined as the amount of enzyme yielding $0.30 \Delta_{\text {abs }}$ in 40 " at RT.

The superoxide dismutase (SOD) activity was measured using a SOD Determination Kit (Sigma-Aldrich, Milano, Italy), according to the supplier's instructions. Since the sample solutions had a visible colour, a "blank 2" lane was set up for each sample as suggested in the manual. One SOD e.u. is defined by the inhibition rate equation indicated in the manual.

\section{Non-structural carbohydrate content}

This assay was also performed on the NX7234 hybrid. The non-structural carbohydrate content (LNSC) was assayed on ear leaves collected at the full dough stage (GS 85) at sunset and the following day at sunrise. Leaf sampling was performed by hand clipping. The samples, composed of 6 whole leaves, were then immediately frozen at $-25^{\circ} \mathrm{C}$ and sent to an external laboratory (Alchim di Masante \& C. s.a.s. Via Roma, 26, 10023 Chieri (TO), Italy) for LNSC quantification by means of an enzymatic assay, and the results were expressed as grams per $100 \mathrm{~g}$ of sample fresh weight (FW).

The photosynthetic efficiency (PE) was calculated as the relation between the diurnal accumulation of LNSC and nocturnal utilization. The following ratio was used (Blandino et al. 2012):

$$
\operatorname{PE}(\%)=\left(\frac{\text { LNSC sunset }- \text { LNSC sunrise }}{\text { LNSC sunset }}\right) \times 100 \text {. }
$$

\section{Yield assessment}

The ears were collected by hand from $13.3 \mathrm{~m}^{2}(2$ rows $\times 5 \mathrm{~m})$ in each plot at the end of maturity and passed through an electric sheller in order to obtain the grain weight. The grain yield was then corrected to a commercial moisture level of $14 \%$.

\section{Statistical analysis}

The effect of fungicide application on the NCLB symptoms was tested separately for each hybrid through an analysis of variance (ANOVA) using a completely randomized block design. When necessary, multiple comparison tests were performed according to the 
Ryan-Einot-Gabriel-Welsh F (REGWF) method. The effect of fungicide application on the LPC, POD and SOD activity and LNSC content was only analysed for NX7234. The effect of fungicide, hybrids and their interaction on grain yield was tested by means of a repeated measure analysis of variance (RM-ANOVA), in which the hybrid was the between-subject factor while the fungicide applications were the within-subject factors. When the effect was significant, the means were compared using the protected Fisher Least Significant Difference (LSD), adjusted for multiple comparisons, using the Bonferroni procedure. The normal distribution and homogeneity of variances were verified by performing the Kolmogorov-Smirnov normality and Levene test for the ANOVA test, whereas Mauchly's sphericity test was used for RM-ANOVA.

SPSS Version 21 for Windows statistical package (SPSS Inc., Chicago) was used for the statistical analysis. The incidence and severity values of NCLB were previously transformed using $\mathrm{y}^{\prime}=\arcsin \sqrt{ } \mathrm{x}^{*} 180 / \pi$, as percentage data derived from counting.

\section{Results}

The meteorological conditions from anthesis to harvest were rather similar between years and locations, therefore no interactions were seen between disease development and the experiments. None of the trial fields or hybrids showed any NCLB presence at the flowering stage (GS 65). On the other hand, a few leaves started to show some disease symptoms at the milk stage, especially on the NX7034 hybrid, where the effect of the fungicide treatment was already visible and significant (Table 2). The NCLB symptoms were more severe on all three hybrids at dough stage, and the benefit of the fungicide treatment was more obvious for both the moderately-resistant (NX7234) and the fully susceptible hybrids (P3235, NX7034). The occurrence of other foliar diseases was negligible for each year and each hybrid. The treatment performed at tassel emergence (T2) was the most effective; it generally halved the incidence compared to the untreated controls. As expected, the moderately-resistant hybrid, NX7234, showed very mild disease symptoms, in comparison to the fully susceptible hybrids, and the effect of fungicide treatment on pathogen development, though detectable, was never significant.

The three hybrids differed significantly from each other $(P=0.022$; standard error of means SEM $=0.772$ ) in terms of average yield: P3235 produced $14.9 \mathrm{t} \mathrm{ha}^{-1}$, NX7034 $13.7 \mathrm{tha}^{-1}$ and NX7234 $15 \mathrm{tha}^{-1}$. Figure 1, which merges the data obtained from different hybrids, shows the effect of fungicide application on grain yield. No interaction between the hybrid and fungicide application was seen $(P=0.782)$, thus the yield response to fungicide application showed a similar trend for each hybrid. The azoxystrobin and propiconazole treatment performed at tassel emergence significantly increased $(P=$ 0.039 ; $\mathrm{SEM}=0.645)$ the yield by $568 \mathrm{~kg} \mathrm{ha}^{-1}(+3.9 \%)$. The application at the beginning of stem elongation also increased yield $(+2.2 \%)$, although this benefit was not significant.

The two fungicide treatments did not significantly influence the LPC, the POD and SOD activity on the NX7234 hybrid (Table 3). The LPC remained stable between the beginning of the dough stage (GS 81) and the full dough stage (GS 85), while the POD activity decreased by $16 \%$ and SOD increased by $7 \%$. 
Table 2. Effect of fungicide treatment on NCLB incidence at the milk stage and incidence and severity at dough stage on differentially susceptible hybrids

\begin{tabular}{|c|c|c|c|c|}
\hline \multirow[t]{2}{*}{ Hybrid } & \multirow[t]{2}{*}{ Treatment } & \multirow{2}{*}{$\begin{array}{l}\text { Milk stage (GS 75) } \\
\text { incidence }^{\dagger}\end{array}$} & \multicolumn{2}{|c|}{ Dough stage (GS 85) } \\
\hline & & & incidence & severity ${ }^{+}$ \\
\hline P3235 & T0 & 1.7 & $49.9 \mathrm{a}^{*}$ & $3.3 \mathrm{a}$ \\
\hline \multirow[t]{4}{*}{ (fully susceptible) } & $\mathrm{T} 1$ & 0.8 & $32.6 \mathrm{~b}$ & $1.0 \mathrm{~b}$ \\
\hline & $\mathrm{T} 2$ & 0.5 & $25.7 b$ & $1.0 \mathrm{~b}$ \\
\hline & $\mathrm{P}(\mathrm{F})$ & 0.147 & 0.007 & 0.001 \\
\hline & SEM $^{\tau}$ & 5.1 & 13.5 & 3.3 \\
\hline NX7034 & T0 & $4.5 \mathrm{a}$ & $45.4 \mathrm{a}$ & $2.9 \mathrm{a}$ \\
\hline \multirow[t]{4}{*}{ (fairly susceptible) } & $\mathrm{T} 1$ & $1.2 \mathrm{~b}$ & $33.1 \mathrm{ab}$ & $1.6 \mathrm{~b}$ \\
\hline & $\mathrm{T} 2$ & $0.9 \mathrm{~b}$ & $18.6 \mathrm{~b}$ & $0.5 \mathrm{c}$ \\
\hline & $\mathrm{P}(\mathrm{F})$ & $<0.001$ & 0.004 & $<0.001$ \\
\hline & SEM & 6.1 & 13.9 & 3.3 \\
\hline NX7234 & T0 & 0.1 & 8.1 & 0.1 \\
\hline \multirow[t]{4}{*}{ (moderately resistant) } & $\mathrm{T} 1$ & 0.1 & 7.8 & 0.2 \\
\hline & $\mathrm{T} 2$ & 0.3 & 5.4 & 0.1 \\
\hline & $\mathrm{P}(\mathrm{F})$ & 0.575 & 0.358 & 0.190 \\
\hline & SEM & 2.5 & 7.9 & 1.0 \\
\hline
\end{tabular}

^ T0, untreated control; T1, application at the beginning of stem elongation (GS 30); T2, application at tassel emergence (GS 51)

${ }^{\dagger}$ Incidence, percentage of leaves showing NCLB symptoms

$\$$ Severity, percentage of leaf surface with NCLB symptoms

* Means followed by different letters are significantly different $P(\mathrm{~F})<0.05$, according to REGWF test

" SEM, standard error of means

The reported values are based on 24 replications ( 4 trials and 6 repetitions).

Table 3. Effect of fungicide treatment on the Leaf Protein Content (LPC), Peroxidase (POD) and Superoxide Dismutase (SOD) activity on NX7234 leaf samples collected at the beginning (GS 81) and at the full dough stage (GS 85)

\begin{tabular}{|c|c|c|c|c|}
\hline Phenological stage & Treatment $^{\wedge}$ & $\begin{array}{c}\mathrm{LPC} \\
\left(\mathrm{mg} \mathrm{g} \mathrm{FW}^{-1 \dagger}\right)\end{array}$ & $\begin{array}{c}\text { POD } \\
\text { (e.u. }{ }^{\ddagger} \mathrm{g} \mathrm{FW}^{-1} \text { ) }\end{array}$ & $\begin{array}{c}\text { SOD } \\
\text { (e.u. } \mathrm{g} \mathrm{FW}^{-1} \text { ) }\end{array}$ \\
\hline \multirow{5}{*}{$\begin{array}{l}\text { Beginning of dough stage } \\
\text { (GS 81) }\end{array}$} & T0 & 3.45 & 50.8 & 681 \\
\hline & $\mathrm{T} 1$ & 3.51 & 50.4 & 603 \\
\hline & $\mathrm{T} 2$ & 3.18 & 50.1 & 722 \\
\hline & $\mathrm{P}(\mathrm{F})$ & 0.422 & 0.993 & 0.126 \\
\hline & SEM* & 1.42 & 33.3 & 312 \\
\hline \multirow{5}{*}{$\begin{array}{l}\text { Full dough stage } \\
\text { (GS 85) }\end{array}$} & T0 & 3.32 & 41.4 & 715 \\
\hline & $\mathrm{T} 1$ & 3.50 & 41.9 & 704 \\
\hline & $\mathrm{T} 2$ & 3.42 & 43.5 & 727 \\
\hline & $\mathrm{P}(\mathrm{F})$ & 0.871 & 0.968 & 0.952 \\
\hline & SEM & 1.80 & 45.9 & 389 \\
\hline
\end{tabular}

- T0, untreated control; T1, application at the beginning of stem elongation (GS 30); T2, application at tassel emergence (GS 51)

${ }^{\dagger}$ FW, Fresh Weight

e.u., enzymatic units

* SEM, standard error of means 


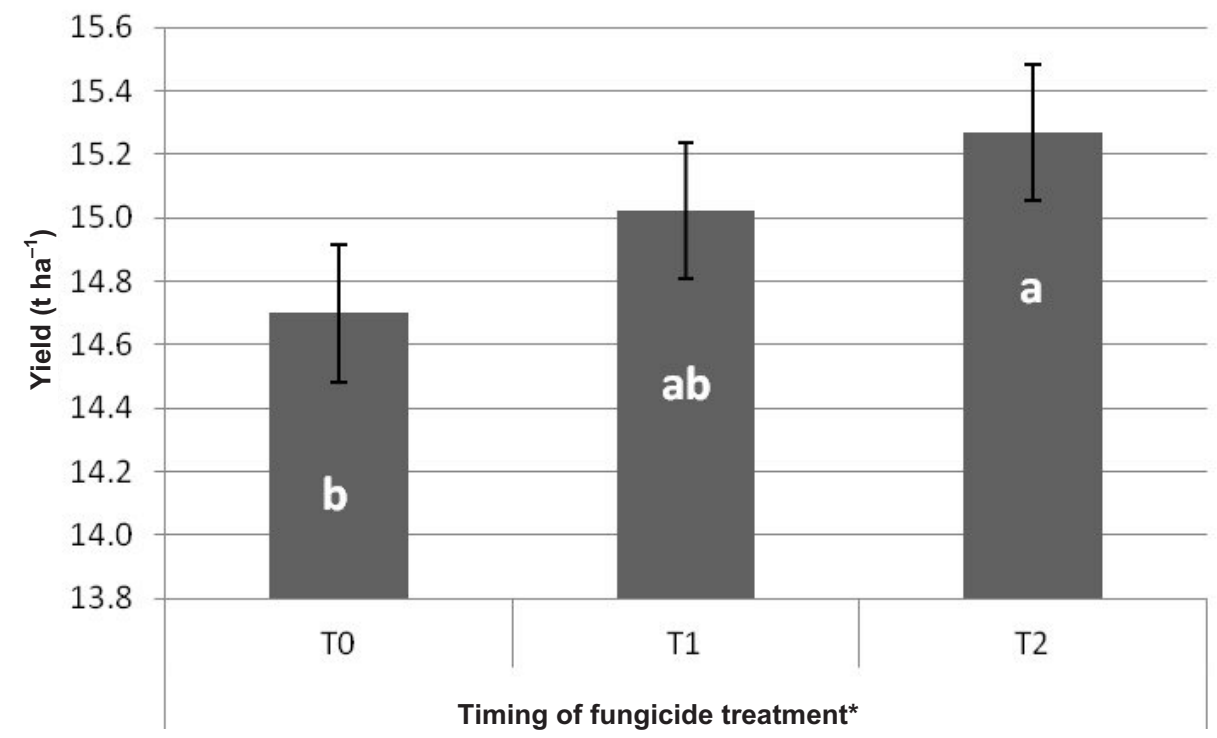

Figure 1. Effect of fungicide treatment on grain yield

Means followed by different letters are significantly different $P(\mathrm{~F})<0.05$, according to Bonferroni test

* T0, untreated control; T1, application at the beginning of stem elongation (GS 30); T2, application at tassel emergence (GS 51). The reported values are based on 56 replications (3 hybrids, 3 trials and 6 repetitions)

The LNSC detected at sunset and sunrise was not influenced by the fungicide treatments. However, the PE, expressed as the ratio of nocturnal utilization of LNSC, was increased by the application of the azoxystrobin and propiconazole mixture, particularly for the $\mathrm{T} 2$ treatment. These differences were not statistically significant.

\section{Discussion}

The fungicide treatment has been shown to control NCLB disease on both susceptible hybrids. This effect was confirmed for both years and both sites. Since the disease usually develops after flowering (GS 65), the most effective fungicide treatment timing is at the tassel emergence (GS 51), as already suggested by Munkvold and Gorman (2006) and by Da Costa and Boller (2008). Plants with healthier leaves than the untreated ones, have a larger photosynthetic area that will increase and prolong the kernel filling phase, which will in turn result in higher yields (Eik and Hanway 1966; Waggoner and Berger 1987).

A previous study (Blandino et al. 2012) showed that a later fungicide application, at the milk stage (GS 75), was as effective as the treatment at tassel emergence (GS 51) for disease control; however, in that case no significant yield increase was seen. This suggested that fungicide application might have a positive effect on maize physiology, besides the obvious benefit of controlling fungal spread at no cost to the plant. 
Table 4. Effect of the fungicide treatment on the Leaf Non-Structural Carbohydrates

(LNSC) content at sunset and sunrise and Photosynthetic Efficiency (PE) in terms of translocation of LNSC from the leaves to the sink during the night on the NX7234 hybrid

\begin{tabular}{|c|c|c|c|}
\hline Treatment $^{\wedge}$ & $\begin{array}{c}\text { LNSC sunset } \\
\left(\mathrm{g} 100 \mathrm{~g} \mathrm{FW}^{-1 \dagger}\right)\end{array}$ & $\begin{array}{l}\text { LNSC sunrise } \\
\left(\mathrm{g} 100 \mathrm{~g} \mathrm{FW}^{-1}\right)\end{array}$ & $\begin{array}{l}\mathrm{PE} \\
(\%)\end{array}$ \\
\hline T0 & 1.22 & 0.79 & 29.1 \\
\hline $\mathrm{T} 1$ & 1.21 & 0.74 & 35.3 \\
\hline $\mathrm{T} 2$ & 1.47 & 0.84 & 39.6 \\
\hline $\mathrm{P}(\mathrm{F})$ treatment & 0.777 & 0.871 & 0.788 \\
\hline SEM* & 0.626 & 0.271 & 22.5 \\
\hline
\end{tabular}

- T0, untreated control; T1, application at the beginning of stem elongation (GS 30);

$\mathrm{T} 2$, application at tassel emission (GS 51)

${ }^{\dagger}$ FW, Fresh Weight

* SEM, standard error of means

For this reason, further investigations were needed to better understand the relationship between grain yield advantage and fungicide treatments. The NCLB symptoms were so mild for the moderately-resistant hybrid NX7234, that the effect of fungicide application, although detectable, was never significant. In spite of this, an increase in grain yield was observed to occur with the same pattern as the other two NCLB-susceptible hybrids. Thus, several aspects of leaf physiology were investigated in order to understand which mechanism was responsible for this phenomenon.

Previous work on wheat suggested that QoI fungicides could help plants reduce the ROS content within the cell by increasing the antioxidant activity of POD and SOD, and the LPC (Wu and von Tiedemann 2001; Zhang et al. 2010). However the present tests did not confirm the previously mentioned effect on maize, neither in the experiments reported here, nor in tests performed on young plants (about 2 months old) of the moderately-resistant hybrid NX7234, under greenhouse conditions (data not shown). Thus the question remains open concerning the physiological effect of fungicide treatments on the plant. It is expected that the balance between ROS and the antioxidant enzymes in the leaf tissues that undergo necrosis because of NCLB colonization, is altered locally; this could have gone unnoticed in the whole-leaf analysis performed here, and yet be relevant to grain yield. However, this scenario is unlikely to explain the increased yield of the fungicide-treated moderately-resistant hybrid compared to the untreated one, since the percentage of necrotizing leaf tissue was also extremely low on the untreated NX7234. Additionally, physiological (non-pathological) leaf senescence is normally correlated to a general LPC decrease (Wu and von Tiedemann 2001), which in the present case, had not started at the time the leaf samples were collected (full dough stage); as a result, the LPC value remained stable between the two sampling times. Therefore, it cannot be ruled out that an effect of fungicide treatment, in this context, would have been detected if physiologically older leaves had been harvested, i.e. when senescence and the associated decrease in LPC and increase in ROS had already started, later during the growing season.

It has been reported that, under stressful conditions, plants often mobilize nutrients and redirect their metabolism to support active defense mechanisms to the detriment of growth 
and final yield (Smith and Moser 1985). Therefore, as an alternative or parallel explanation, it is plausible that the active containment of fungal growth in the leaves of the NCLB-moderately-resistant hybrid NX7243 occurred at the expense of the final grain yield. If this were the case, then the azoxystrobin and propiconazole mixture might have prevented the triggering of active defense mechanisms by killing the inoculum prior to infection and/or attempted tissue colonization. This would allow the allocation of more metabolic resources to the sink organ and lead to a better yield.

Other physiological effects for fungicide treatments have been reported, but have not been explored in this study. For example, the strobilurin treatment of C3 plants, such as wheat, barley and soybean, has been shown to reduce stomatal conductance (Nason et al. 2007) whereas triazole positively affected photosynthesis by enhancing the chlorophyll content (Petit et al. 2012). A deeper understanding of the reaction of these two parameters to fungicide application is also needed for maize, in order to mechanistically explain the observed yield increase and to better exploit these chemicals, not only to control fungal diseases but also as crop enhancers.

\section{Acknowledgements}

The authors would like to thank Francesco Amato, Giovanni Berrino, Doriana Francia, Federico Marinaccio, Giacomo Sala and Marcello Valente for their expert technical assistance. The research was conducted with the financial support of the Regione Piemonte, as a part of the ALIMAIS project, and Syngenta Crop Protection S.p.A.

\section{References}

Alscher, R.G., Donahue, J.L., Cramer, C.L. 1997. Reactive oxygen species and antioxidants: Relationships in green cells. Physiol. Plant. 100:224-233.

Blandino, M., Galeazzi, M., Savoia, W., Reyneri, A. 2012. Timing of azoxystrobin + propiconazole application on maize to control northern corn leaf blight and maximize grain yield. Fields Crop. Res. 139:20-29.

Bowen, K.L., Pedersen, W.L. 1988. Effects of propiconazole on Exserohilum turcicum in laboratory and field studies. Plant Dis. 72:847-850.

Bradford, M.M. 1976. A rapid and sensitive method for the quantitation of microgram quantities of protein utilizing the principle of protein-dye binding. Anal. Biochem. 72:248-254.

Bradley, C.A., Ames, K.A. 2010. Effect of foliar fungicides on corn with simulated hail damage. Plant Dis. 94:83-86.

Cunha, J.P.A.R., da Silva, L.L., Boller, W., Rodriguez, J.F. 2010. Aplicação aérea e terrestre de fungicida para o controle de doenças do mihlo (Aerial and ground fungicide application to corn for disease control). Rev. Ciència Agron. 41:366-372.

Da Costa, D.I., Boller, W. 2008. Aerial and ground applications of fungicide for the control of leaf disease in maize crop (Zea mays L.). CIGR - Int. Conf. Agric. Eng. Foz do Iguaçu. PR, Brazil. Available at http://www.dpaviacao.com.br/Fungic.pdf

Del Rio, L.A., Pastori, G.M., Palma, J.M., Sandalio, L.M., Sevilla, F., Corpas, F.J., Jiménez, A., Lòpez-Huertas, E., Hernàndez, J.A. 1998. The activated oxygen role of peroxisomes in senescence. Plant Physiol. 116:1195-1200.

Diedhiou, P.M., Oerke, E.-C., Dehne, H.-W. 2004. Effects of the strobilurin fungicides azoxystrobin and kresoxim methyl on arbuscular mycorrhiza. J. Plant Dis. Prot. 111:545-556.

Eik, K., Hanway, J.J. 1966. Leaf area in relation to yield of corn grain. Agron. J. 58:16-18. 
Ekmekci, Y., Terzioglu, S. 2005. Effects of oxidative stress induced by paraquat on wild and cultivated wheats. Pestic. Biochem. Physiol. 83:69-81.

Hooker, D., Tenuta, A., Stewart, G. 2009. Impact of foliar fungicides on corn hybrids. Field Crop Report 1:1-4. Available at http://www.ontariosoilcrop.org/docs/v6cor4.pdf.

Kumar, S., Rani, A., Jha, M.M. 2009. Efficacy of fungicides against Helminthosporum maydis of maize. Ann. Plant Prot. Sci. 17:255-256.

Lancashire, P.D., Bleiholder, H., van den Boom, T., Langeluddeke, P., Stauss, R., Weber, E., Witzenberger, A. 1991. A uniform decimal code for growth stages of crops and weeds. Ann. Appl. Biol. 119:561-601.

Munkvold, G., Gorman, D. 2006. Foliar fungicide use in corn. Crop Insights 16:1-6. Available at http://media.agricharts.com/sites/210/CropInsights/6.

Nason, M.A., Farrar, J., Bartlett, D. 2007. Strobilurin fungicides induce changes in photosynthetic gas exchange that do not improve water use efficiency of plants grown under conditions of water stress. Pest Manag. Sci. 63:1191-1200.

Petit, A.-N., Fontaine, F., Vatsa, P., Clément, C., Vaillant-Gaveau, N. 2012. Fungicide impacts on photosynthesis in crop plants. Photosynth. Res. 111:315-326.

Prochazkova, D., Sairam, R.K., Srivastava, G.C., Singh, D.V. 2001. Oxidative stress and antioxidant activity as the basis of senescence in maize leaves. Plant Sci. 161:765-771.

Smith, G.A., Moser, H.S. 1985. Sporophytic-gametophytic herbicide tolerance in sugarbeet. Theor. Appl. Genet. 71:231-237.

Thompson, J.E., Legge, R.L., Barber, R.F. 1987. The role of free radicals in senescence and wounding. New Phytol. 105:317-344.

Waggoner, P.E., Berger, R.D. 1987. Defoliation, disease, and growth. Phytopathol. 77:393-398.

Wang, L., Zhao, J.-Y., Wu, S.-M., Pan, J.-L., Huang, Z.-B., Wu, Z.-K., Fan, X.-W., Li, Y.-Z. 2011. No statistic correlation between superoxide dismutase and peroxidase activities and aluminum-induced lipid peroxidation in maize, implying limited roles of both enzymes in prevention against aluminum-induced lipid peroxidation. Am. J. Plant Sci. 2:156-164.

White, D.G. 1999. Compendium of Corn Diseases. $3^{\text {rd }}$ Edition. APS Press, St. Paul, MN, USA.

Wise, K.., Mueller, D., 2011. Are Fungicides no longer just for Fungi? An Analysis of foliar fungicide use in corn. APSnet Features, available at http://dx.doi.org/10.1094/APSnetFeature-2011-0531.

Wu, Y.-X., von Tiedemann, A. 2001. Physiological effects of azoxystrobin and epoxiconazole on senescence and the oxidative status of wheat. Pestic. Biochem. Physiol. 71:1-10.

Zhang, Y.-J., Zhang, X., Chen, C.-J., Zhou, M.-G., Wang, H.-C. 2010. Effects of fungicides JS399-19, azoxystrobin, tebuconazole, and carbendazim on the physiological and biochemical indices and grain yield of winter wheat. Pestic. Biochem. Physiol. 98:151-157. 